\title{
Możliwość zatrudniania przez wójta pełnomocników na podstawie umów cywilnoprawnych ${ }^{1}$
}

\footnotetext{
The possibility of employing proxies by a head of commune on the basis of civil law contracts: The professional performance of public tasks results in the necessity to employ persons who treat the performance of these tasks as a profession and therefore should be employed within the framework of an employment relationship. Therefore, it is not possible to employ proxies under a civil law contract to perform official tasks. Employment on such a position under a civil-law contract can be assessed as a circumvention of rules, according to which local government employees should be employed - including the rules established in terms of recruitment, qualifications and duties.
}

Keywords: commune, labour, employees, local self-government, contract

Słowa kluczowe: gmina, praca, pracownicy, samorząd terytorialny, umowa

\section{Przedmiot opinii}

Przedmiotem niniejszej opinii jest udzielenie odpowiedzi na następujące pytanie: czy w obecnym stanie prawnym dopuszczalne jest powoływanie przez wójta pełnomocnika, w osobie fizycznej niebędącej pracownikiem gminy, i powierzenie mu obowiązków na podstawie umowy cywilnoprawnej?

Pytanie powyższe zostało postawione wraz $\mathrm{z}$ opisem praktyki powoływania po ostatnich wyborach samorządowych "pracowników do zadań specjalnych” (w poprzedniej kadencji samorządu funkcje takie pełnili doradcy lub asystenci zatrudniani poza procedurą konkurencyjnego naboru). Jako przykład wskazano zatrudnienie przez prezydenta miasta na postawie umowy cywilnoprawnej pełnomocnika ds. społecznych. Do zadań tego pełnomocnika należy m.in.:

1 Opinia prawna w sprawie możliwości zatrudniania przez wójta pełnomocników na podstawie umów cywilnoprawnych sporządzona 20 marca 2019 r. na zlecenie posła Klubu Parlamentarnego Prawo i Sprawiedliwość; BAS-WAP 319/19. 
- koordynowanie zadań związanych z rozwojem polityki społecznej, edukacji, kultury, sportu turystyki i promocji miasta,

- monitorowanie procesu wdrażania funduszy europejskich oraz analizowanie czynników sprzyjających rozwojowi regionalnemu (pod kątem optymalnej realizacji działań w odniesieniu do przyszłego okresu programowania i polityk UE),

- koordynowanie współpracy międzynarodowej miasta,

- koordynowanie pierwszej miejskiej strategii dla młodzieży w regionie,

- koordynowanie prac nad stworzeniem i wdrażaniem strategii na rzecz rozwoju wysokiej jakości usług społecznych,

- poprawa jakości kształcenia: koordynacja współpracy jednostek oświatowych i przedsiębiorców,

- wdrożenie rozwiązań na rzecz czystego powietrza (koordynacja działań na rzecz poprawy jakości powietrza w mieście),

- integracja cudzoziemców,

- koordynowanie współpracy z organizacjami pozarządowymi.

Opinia została przygotowana z uwzględnieniem następujących aktów prawnych:

- ustawa z 21 listopada 2008 r. o pracownikach samorządowych, t.j. Dz.U. 2018, poz. 1260 , ze zm.,

- ustawa z 26 czerwca 1974 r. - Kodeks pracy, t.j. Dz.U. 2018, poz. 917, ze zm.,

- ustawa z 21 listopada 2008 r. o służbie cywilnej, t.j. Dz.U. 2018, poz. 1559,

- rozporządzenie Rady Ministrów z 15 maja 2018 r. w sprawie wynagradzania pracowników samorządowych, Dz.U. poz. 936, ze zm.

\section{Możliwość zatrudniania przez organ samorządu terytorialnego pełnomocnika na podstawie umów cywilnoprawnych}

1. Zgłoszony problem należy rozpatrywać przede wszystkim z punktu widzenia zasad funkcjonowania administracji samorządu terytorialnego ustalonych $\mathrm{w}$ art. 1 ustawy o pracownikach samorządowych. Zgodnie z tym przepisem: $W$ celu zapewnienia zawodowego, rzetelnego i bezstronnego wykonywania zadań publicznych przez samorzad terytorialny ustanawia się przepisy prawa pracy określające status prawny pracowników samorządowych.

W komentarzu do art. 1 powołanej ustawy stwierdzono: Pierwszym $z$ aksjomatów, o których mowa w treści komentowanego artykułu, jest zawodowe wykonywanie zadan publicznych przez samorzad terytorialny. W znaczeniu słownikowym pojęcie „zawodowy” jest definiowane jako „będacy kimś z zawodu, trudniący się czymś stale, w ramach swojego zawodu" (por. "Słownik języka polskiego PWN", Warszawa 1969, s. 990). Zawodowe wykonywanie zadań oznacza zatem profesjonalizm ogólnie wymagany $w$ ramach regulacji prawnych od pracowników samo- 
rzadu terytorialnego, natomiast dla zajmowania konkretnego stanowiska pewnych kwalifikacji szczególnych (por. wyrok TK z dnia 12 grudnia 2002 r., K 9/02, OTK-A 2002, nr 7, poz. 94). Wobec tego zawodowe wykonywanie zadań publicznych oznacza konieczność zatrudniania osób, które traktuja wykonywanie tych zadań jako zawód. Zatrudnienie $w$ samorządzie terytorialnym nie ma charakteru zajęcia przejściowego, lecz stanowi stałe źródło utrzymania oraz miejsce pracy zapewniajace osobom kompetentnym możliwość realizacji kariery zawodowej. Jednocześnie jest to takie działanie, które pracownik samorzadu terytorialnego, pojmując swoja pracę jako służbę, podejmuje w zgodzie z powszechnie obowiązującymi przepisami prawa, a ponadto $w$ sposób lojalny wobec państwa $i$ urzędu podporzadkowuje się poleceniom służbowym przełożonego (por. W. Drobny [w:] W. Drobny, M. Mazuryk, P. Zuzankiewicz, „Ustawa o służbie cywilnej. Komentarz”, Warszawa 2010, s. 38 i n. $)^{2}$.

$\mathrm{Na}$ aspekt zawodowego, czyli trwałego, wykonywania zadań przez służbę publiczną (a więc również przez administrację samorządu terytorialnego) zwraca uwagę B. Jaworska-Dębska, która stwierdza, że służba publiczna wymaga, aby udział w działalności instytucji publicznej miał charakter trwały, a stosunek danej osoby z instytucją publiczną - charakter pracowniczy lub quasi-pracowniczy - bez względu na formę jego nawiązania oraz na nazwę stanowiska³.

Istotny wydaje się przy tym fakt, że ustawowe standardy funkcjonowania samorządowej służby publicznej są zbliżone do tych, które dotyczą całej służby publicznej, w tym służby cywilnej. Ustalony w art. 1 ustawy o pracownikach samorządowych wymóg zawodowości - obok rzetelności i bezstronności wykonywania zadań publicznych - pracowników samorządowych koresponduje z podobnym katalogiem podstawowych wartości, które powinny być podstawą wykonywania zadań publicznych przez korpus służby cywilnej, jakie zostały ustalone w art. 153 ust. 1 Konstytucji ${ }^{4}$ oraz w art. 1 ustawy o służbie cywilnej ${ }^{5}$.

W wyroku o sygn. akt K 51/02 odnoszącym się do służby cywilnej Trybunał Konstytucyjny podkreślił, że zawodowe wykonywanie zadań państwa oznacza

2 W. Drobny [w:] W. Drobny, M. Mazuryk, P. Zuzankiewicz, Ustawa o pracownikach samorzadowych. Komentarz, 2010, LEX.

3 B. Jaworska-Dębska, Stużba publiczna w samorządzie terytorialnym [w:] Służba publiczna. Stan obecny, wyzwania i oczekiwania, red. S. Płatek, 2013, LEX. Autorka ta powołuje się na pogląd wyrażony przez W. Sokolewicza w komentarzu do art. 60 Konstytucji RP [w:] Konstytucja Rzeczypospolitej Polskiej. Komentarz, t. IV, red. L. Garlicki, Warszawa 2005, s. 14-17.

4 Art. 153 ust. 1. W celu zapewnienia zawodowego, rzetelnego, bezstronnego i politycznie neutralnego wykonywania zadań państwa, w urzędach administracji rządowej działa korpus stużby cywilnej.

5 Art. 1. W celu zapewnienia zawodowego, rzetelnego, bezstronnego i politycznie neutralnego wykonywania zadań państwa ustanawia się służbę cywilnq oraz określa zasady dostępu do tej służby, zasady jej organizacji, funkcjonowania i rozwoju. 
konieczność zatrudniania osób, które traktują wykonywanie tych zadań jako zawód. W opinii Trybunału: Oznacza to, że zatrudnienie w ramach służby cywilnej nie ma być jedynie przejściowym zajęciem, ale stałym źródłem utrzymania oraz miejscem pracy, zapewniajacym osobom kompetentnym możliwość realizacji kariery zawodowej.

Barbara Jaworska-Dębska, omawiając wymóg zawodowego działania samorządowej służby publicznej, stwierdza, że pojęcie „zawodowy” jest rozumiane w znaczeniu potocznym (słownikowym) m.in. jako „zajęcie wykonywane jako zawód", zaś w orzecznictwie (autorka powołuje wyrok TK w sprawie o sygn. akt K 9/02) przyjmuje się, że zawodowość oznacza profesjonalizm ogólnie wymagany w ramach regulacji prawnych od pracowników, a dla zajmowania konkretnego stanowiska pewnych kwalifikacji szczególnych (w ten sam sposób TK w wyroku o sygn. akt K 51/02).

W wyroku o sygn. akt K 51/02 Trybunał Konstytucyjny wskazał również, że gwarancją, iż w wyniku naboru nie trafią do służby cywilnej osoby przypadkowe, jest katalog rygorów selekcyjnych. Trybunał zwrócił uwagę na to, że niezwykle ważną funkcję związaną z zapewnieniem instytucjom państwowym odpowiedniej liczby wysoko wykwalifikowanych pracowników stanowi trwałość stosunku pracy w służbie publicznej (jeśli członkowie korpusu służby cywilnej nie są jednak w stanie sprostać stawianym im wymogom odnoszącym się do zawodowego pełnienia zadań publicznych, muszą się liczyć z zakończeniem zatrudnienia).

W podobny sposób został ukształtowany otwarty i konkurencyjny nabór, wymogi selekcyjne i warunki kontynuacji zatrudnienia w charakterze pracownika samorządowego. Zatrudnianie poza tym naborem, jak również powierzanie zadań osobom, które je realizują poza stosunkiem pracy, m.in. bez ustalenia ich kwalifikacji zawodowych, przeczy omawianej zasadzie zawodowości wynikającej $\mathrm{z}$ art. 1 ustawy o pracownikach samorządowych.

2. W kwestii braku możliwości zatrudniania pracowników samorządowych na podstawie umów prawa cywilnego wypowiedział się w sposób jednoznaczny A. Sobczyk ${ }^{6}$. Autor ten uznał, że podstawową barierą stosowania umów prawa cywilnego w zatrudnieniu urzędniczym jest hierarchiczność urzędu, za która idzie oczekiwane podporządkowanie. A. Sobczyk rozważając m.in. możliwość zatrudniania $\mathrm{w}$ ramach umów cywilnoprawnych na stanowiskach $\mathrm{z}$ wyboru, stwierdził, że: [...] w literaturze przedmiotu występuja znacznie dalej idące zastrzė̇enia, które zatrudnienie cywilnoprawne - jeśli w ogóle dopuszczaja - to wyłącznie na potrzeby wykonania usług doraźnych. Stawia się tezę, że stałe czynności moga być wykonywane wyłacznie przez pracowników samorzadowych. Ewentualne wyjątki moga wynikać wyłącznie z treści statutów danej jednostki organizacyjnej, moga

6 A. Sobczyk, Nietypowe formy zatrudnienia a zatrudnienie pracowników samorząowych [w:] Służba publiczna. Stan obecny, wyzwania i oczekiwania, red. S. Płażek, 2013, LEX. 
być ograniczone wyłącznie do członków zarządu oraz tylko do czynności o charakterze organizacyjnym ${ }^{7}$.

Arkadiusz Sobczyk uznaje, że nie jest możliwe stosowanie zatrudnienia cywilnoprawnego w odniesieniu do stanowisk urzędniczych. W jego opinii takie zatrudnienie: [...] zdaje się być niewykluczone w stosunku do osób zatrudnionych na stanowiskach pomocniczych oraz doradców. Choć od razu należy dodać, że jest to przede wszystkim wnioskowanie według zasady in dubio pro libertate, czyli niewynikajace wprost $z$ przepisów ${ }^{8}$.

3. Na temat zatrudniania na stanowiskach doradców i asystentów, a przede wszystkim zasadności zaliczania tych stanowisk do służby publicznej wypowiedziała się B. Jaworska-Dębska, uznając, że choć stanowiska doradców i asystentów nie są stanowiskami stricte urzędniczymi, to jednak ustawodawca wiąże je $\mathrm{z}$ tą grupą pracowników samorządowych (głównie w zakresie pewnego reżimu, któremu są poddani urzędnicy - chodzi zwłaszcza o obowiązek złożenia oświadczenia o prowadzeniu działalności gospodarczej oraz o obowiązek - na żądanie osoby uprawnionej do dokonywania czynności w sprawach z zakresu prawa pracy - złożenia oświadczenia o stanie majątkowym) ${ }^{9}$.

Powyższe wnioski należy odnieść do rozważanej możliwości zatrudniania pełnomocników w ramach umów cywilnoprawnych. Z dotychczas zaprezentowanego stanowiska doktryny i judykatury wynika, że ustawa o pracownikach samorządowych nie pozwala na inne formy zatrudniania pracowników merytorycznych (pracowników na stanowiskach urzędniczych) niż w ramach stosunku pracy. Co więcej, jeśli ustawodawca zrezygnował z możliwości zatrudniania w samorządzie doradców i asystentów ${ }^{10}$, oznacza to, że pracodawca samorządowy może zatrudniać zgodnie $\mathrm{z}$ art. 4 ust. 2 ustawy o pracownikach samorządowych ${ }^{11}$ wyłącznie na stanowiskach urzędniczych oraz pomocniczych obsługi, a więc tylko w ramach stanowisk ustalonych przepisami rozporządzenia Rady Ministrów w sprawie wynagradzania pracowników samorządowych. Wśród tych stanowisk nie przewidziano stanowiska „pełnomocnik”12. Zatrudnianie na takim stanowisku na podstawie umowy cywilnoprawnej można ocenić jako obejście zasad, według których powinni być zatrudniani pracownicy samorządowi - w tym zasad

7 Ibidem. Autor powołuje się na J. Stelinę, Prawo urzędnicze, Warszawa 2009, s. 90.

8 A. Sobczyk, Nietypowe formy zatrudnienia, op. cit.

9 B. Jaworska-Dębska, Stużba publiczna, op. cit.

10 Ustawa z 15 września 2017 r. o zmianie ustawy o pracownikach samorządowych, Dz.U. poz. 1930.

11 Art. 4 ust. 2. Pracownicy samorządowi sa zatrudniani na stanowiskach: 1) urzędniczych, w tym kierowniczych stanowiskach urzędniczych; 2) (uchylony); 3) pomocniczych i obstugi.

12 Poza tematem niniejszej opinii pozostaje kwestia, czy katalog stanowisk przewidziany w omawianych przepisach jest wystarczający i czy może sprostać wszystkim realnym potrzebom urzędów zatrudniających pracowników samorządowych. 
ustalonych w zakresie naboru, kwalifikacji, obowiązków (w tym również tych, które mają zapobiegać korupcji, takich jak oświadczenia o działalności gospodarczej czy oświadczenie majątkowe).

4. Z omawianych przepisów wynika, że osoby zatrudniane na podstawie umów cywilnoprawnych nie powinny być wyposażone w kompetencje urzędnicze, a tym bardziej kierownicze w stosunku do pracowników samorządowych zatrudnionych w danej jednostce organizacyjnej.

W świetle omawianych regulacji contra legem byłoby zatrudnienie na podstawie umowy cywilnoprawnej pełnomocnika, który kierowałby komórką (komórkami) organizacyjnymi urzędu gminy lub w inny sposób był przełożonym (koordynatorem) pracowników tego urzędu. Rola takiego „pełnomocnika” mogłaby mieć charakter wyłącznie wspierający (techniczno-pomocniczy), a zatem osoba wykonująca umowę-zlecenia jako pełnomocnik nie powinna podejmować żadnych czynności merytorycznych (a zwłaszcza decyzyjnych) w zakresie zadań danej jednostki samorządu terytorialnego.

Z przedstawionej listy zadań pełnomocnika prezydenta miasta ds. społecznych można wnioskować, że niektóre z zadań mieszczą się w czynnościach merytorycznych, a nawet decyzyjnych (czyli urzędniczych), co jest sprzeczne z zasadami omówionymi wyżej.

5. Na zakończenie należy zwrócić uwagę na aspekt dodatkowy, jakim jest wykonywanie określonych zadań w siedzibie urzędu, w godzinach jego pracy i pod nadzorem przełożonego (np. burmistrza), co może świadczyć o tym, że umowy takie byłyby wykonywane w rzeczywistości w ramach stosunku pracy, o którym mowa $\mathrm{w}$ art. $22 \S 1-1^{1}$ Kodeksu pracy ${ }^{13}$. Stanowiłoby to naruszenie zakazu zastępowania umów o pracę umowami cywilnoprawnymi określonego $\mathrm{w}$ art. $22 \$ 1^{2}$ Kodeksu pracy ${ }^{14}$, a także nakazu wynikającego $\mathrm{z}$ art. 4 ustawy o pracownikach samorządowych.

\section{Podsumowanie}

Przychylając się do podglądów wyrażanych w doktrynie (zbieżnych zarówno z potocznym rozumieniem „zawodowości”, jak i z jego rozumieniem przyjętym w orzecznictwie), należy uznać, że zawodowe wykonywanie zadań publicz-

13 Art. $22 \$ 1$. Przez nawiązanie stosunku pracy pracownik zobowiąuje się do wykonywania pracy określonego rodzaju na rzecz pracodawcy i pod jego kierownictwem oraz $w$ miejscu i czasie wyznaczonym przez pracodawce, a pracodawca - do zatrudniania pracownika za wynagrodzeniem. $\$ 11$. Zatrudnienie $w$ warunkach określonych $w \$ 1$ jest zatrudnieniem na podstawie stosunku pracy, bez względu na nazwe zawartej przez strony umowy.

14 Art. $22 \$ 1^{2}$. Nie jest dopuszczalne zastapienie umowy o prace umowa cywilnoprawna przy zachowaniu warunków wykonywania pracy, określonych $w \$ 1$. 
nych oznacza konieczność zatrudniania osób, które traktują wykonywanie tych zadań jako zawód, a więc powinny być zatrudniane w ramach stosunku pracy. W związku z tym (przede wszystkim z uwagi na art. 1 i 4 ustawy o pracownikach samorządowych) nie jest możliwe zatrudnianie w ramach umowy cywilnoprawnej pełnomocników, którzy wykonywaliby zadania urzędnicze. Zatrudnianie na takim stanowisku w ramach umowy cywilnoprawnej można ocenić jako obejście zasad, według których powinni być zatrudniani pracownicy samorządowi w tym zasad ustalonych w zakresie naboru, kwalifikacji i obowiązków.

\section{Bibliografia}

Drobny W. [w:] W. Drobny, M. Mazuryk, P. Zuzankiewicz, Ustawa o pracownikach samorzadowych. Komentarz, 2010, LEX.

Jaworska-Dębska B., Służba publiczna w samorządzie terytorialnym [w:] Stużba publiczna. Stan obecny, wyzwania i oczekiwania, red. S. Płatek, 2013, LEX.

Sobczyk A., Nietypowe formy zatrudnienia a zatrudnienie pracowników samorządowych [w:] Stużba publiczna. Stan obecny, wyzwania i oczekiwania, red. S. Płażek, 2013, LEX.

Sokolewicz W., Komentarz do art. 60 [w:] Konstytucja Rzeczypospolitej Polskiej. Komentarz, t. IV, red. L. Garlicki, Warszawa 2005.

Stelina J., Prawo urzędnicze, Warszawa 2009. 